Review

\title{
Consumption of Atlantic Salmon Smolt by Striped Bass: A Review of the Predator-Prey Encounter Literature and Implications for the Design of Effective Sampling Strategies
}

\author{
Samuel N. Andrews ${ }^{1, *}$, Sarah V. Hirtle ${ }^{1}$, Tommi Linnansaari ${ }^{1,2}$ and R. Allen Curry ${ }^{1,2}$ \\ 1 Department of Biology, University of New Brunswick, Canadian Rivers Institute, Fredericton, NB E3B 5A3, \\ Canada; sarah.hirtle@unb.ca (S.V.H.); t.linnansaari@unb.ca (T.L.); racurry@unb.ca (R.A.C.) \\ 2 Faculty of Forestry and Environmental Management, University of New Brunswick, P.O. Box 4400, \\ Fredericton, NB E3B 5A3, Canada \\ * Correspondence: sandrew2@unb.ca
}

Received: 19 July 2019; Accepted: 24 September 2019; Published: 11 October 2019

\begin{abstract}
The native striped bass (Morone saxatilis) population of the Miramichi River, New Brunswick is undergoing an unprecedented recovery while Atlantic salmon (Salmo salar) numbers within that system continue to decline. Atlantic salmon smolt depart from the Miramichi system during the striped bass spawning period and it is hypothesized that elevated striped bass abundances will increase encounter rates and predation on smolts. We summarize all available striped bass diet studies occurring within the native range of Atlantic salmon and present a review of the feeding behavior and diet preferences of striped bass before, during, and after their spawning period. The key studies vary in methodologies and interpretability. We present a standardized approach for assessing striped bass predation threats and smolt vulnerability and thus an improved understanding of the species interactions to guide future management in the Miramichi River.
\end{abstract}

Keywords: Conservation; diet; management; methodology; monitoring; predation; striped bass; Atlantic salmon

\section{Introduction}

The overlapping native range of striped bass (Morone saxatilis) and Atlantic salmon (Salmon salar) extends nearly $1500 \mathrm{~km}$ from the southern extreme of the Atlantic salmon range in the Hudson River, USA [1] to the northern extreme of the striped bass range in the Saint Lawrence River, Canada [2] (Figure 1). Within this area, 300 rivers currently support Atlantic salmon populations (either native or re-introduced by stocking) [3,4] and six rivers (Hudson, Kennebec, Saint John, Shubenacadie, Miramichi, and Saint Lawrence) are recognized to support reproducing populations of striped bass [5-7].

Many US Atlantic salmon populations were extirpated by the early 1800 s as a result of anthropogenic effects such as dam construction, pollution, and overfishing [8-11]. Remaining US Atlantic salmon populations [3,4] exist largely through the efforts of intensive stocking [12], strict angling regulations (e.g., no retention), and habitat remediations [13] that address the most visible threats to the species. Throughout the Canadian range, wild Atlantic salmon returns persist in numerous rivers, although, in many instances, adult returns are low [14]. Declining Atlantic salmon populations (particularly in the southern species range) has led to extirpated and/or threatened status for the species in several rivers (e.g., those of the Inner Bay of Fundy [15], Merrimack, Kennebec [16]) and numerous additional rivers are failing to meet their conservation targets [12,17]. In response, conservation efforts are now beginning to address many less tangible and wide-reaching ecological threats such as competition from escaped aquaculture origin adults [18], warming waters [19], and predation [20]. 
One documented Atlantic salmon predator is the striped bass. This species enters their natal rivers in spring to spawn (e.g., [6]) such that their spawning period juxtaposes them both temporally and spatially with the river exodus of Atlantic salmon smolts (e.g., [21]). This period is cited as the greatest occurrence of smolt predation by striped bass (e.g., [20,22]). Although there is limited geographical overlap between striped bass and Atlantic salmon spawning rivers (only six support native populations of both species), the migration of adult striped bass along coastal habitats [23], a preference for river estuaries [24], and frequent forays up coastal tributaries [25] leave no shortage of opportunities for potential predator/prey interactions.

The interaction between striped bass and Atlantic salmon smolts has drawn growing scientific and public attention as many striped bass populations are in a state of recovery [22,26]. As striped bass populations expand in both numbers $[27,28]$ and habitat range (e.g., striped bass are now documented in Labrador [29]), the probability of striped bass encountering and predating on threatened Atlantic salmon is likely to increase. Nowhere is this possibility more apparent than on the Miramichi River, New Brunswick (e.g., [20]). The Miramichi River's Atlantic salmon population has been declining [30] while the striped bass, once harvested to the brink of extinction [31], recovered to a peak of 1-2 million spawners in 2017 [32] following an 11-year moratorium on all striped bass fisheries in 2000 and a 21-year commercial closure [22]. Managers are concerned about species interactions, specifically adult striped bass and salmon smolts, and conflicts among the fisheries they support.

The Miramichi River situation has triggered substantial management debates locally over whether to severely restrict the abundance of one native and recently recovered predator (i.e., the striped bass) in order to protect the Atlantic salmon which has faced a long-term decline. However, it is a bellwether for the other rivers where the two species coexist, especially as the striped bass appears to recover and extend their range across that of declining Atlantic salmon populations. As a first step to support the challenging management environment these two species are creating, we investigated and report on one key potential conflict, which is the potential predation impacts of striped bass on Atlantic salmon smolts. We summarized the known striped bass diet in waters where the species co-exist, the feeding behavior of striped bass during the time of greatest overlap with smolt, i.e., pre-, during, and post-spawning by striped bass, and proposed a standardization of methods to accurately assess the predation threat for future studies. Our goal was to promote a balanced conservation and recovery of both the striped bass and the Atlantic salmon in the Miramichi and other rivers throughout the overlapping species range.

\section{Materials and Methods}

Striped bass diet studies conducted within their overlapping range with Atlantic salmon (Figure 1, Figure A1) were compiled and then subdivided into three categories: diet of young-of-the-year (YOY), yearling, and small juvenile $<20 \mathrm{~cm}$ Fork Length (FL) striped bass (Table A1, Figure 1A); diet of adult, sub-adult, and large, juvenile striped bass $>20 \mathrm{~cm}$ FL in coastal and marine environments (Table A1, Figure 1A); and diets of adult, sub-adult, and large juvenile striped bass $>20 \mathrm{~cm}$ FL in rivers supporting Atlantic salmon (Table 1, Figure 1). Striped bass $<20 \mathrm{~cm}$ that were classified in the first group of studies $(n=8)$ typically occupy warm coastal and estuary habitats [6] and the individuals were deemed too small to consume migrating smolts [33,34]. Striped bass sampled in coastal waters as a part of the second group of studies $(n=9)$ were often sampled during mid-summer in tidal lagoons, from beaches, or offshore and would be unlikely to encounter smolts. No study in either of these two groups documented smolt or salmonid predation (Table A1; Figure 1A). Accordingly, we focused on the third category of studies $(n=15)$ because they included striped bass that were large enough to consume Atlantic salmon smolts in habitats where they could be encountered (Table 1; Figure 1).

Of the 15 studies where predation on smolts was possible, four ([35-37] and a secondary study in [22]) were omitted from the analysis due to the lack or absence of detailed information on sampling locations and diet (Table 1). Two additional studies [38,39] were excluded because they occurred in winter outside the smolt migration period. As a final omission, 13 striped bass (size range 
201-275 mm) sampled by Gardinier and Hoff [40] were also excluded as their stomach contents were inseparably pooled with individuals ranging from $<76 \mathrm{~mm}$ to $200 \mathrm{~mm}$ (Table 1). These seven omitted studies reported only one smolt and one parr amongst 3557 collected stomach samples (Tables 1 and 2). The eight remaining studies accurately enumerated and documented to species all food items consumed by sampled striped bass during the presumed smolt out-migration period.
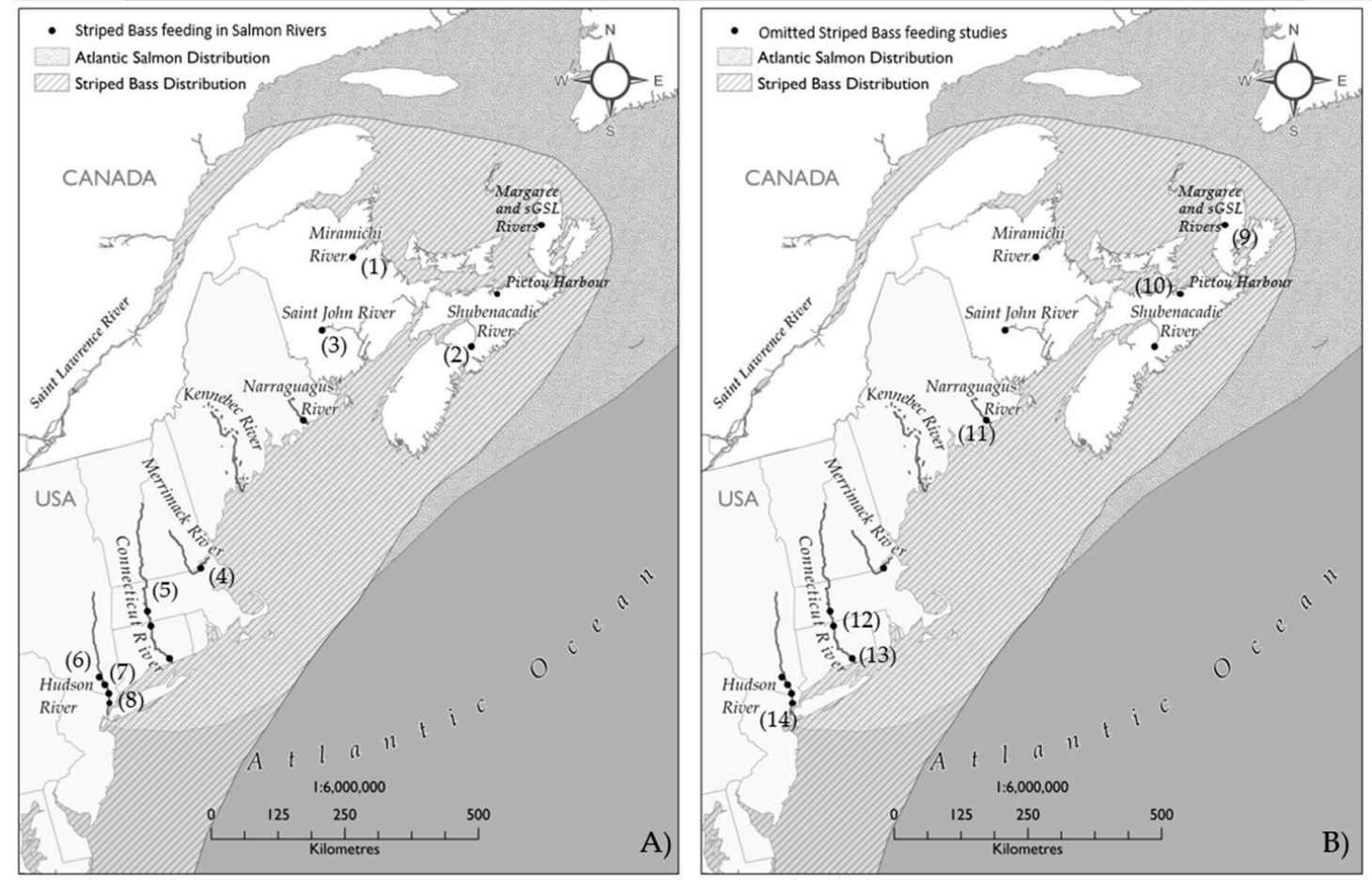

Figure 1. Maps depicting the overlapping range of Atlantic salmon (grey stippled region extending north) and striped bass (grey striped region extending south) along the Atlantic Coast of the United States and Canada. The numbered points on the left panel (A) indicate the dietary studies conducted on adult, sub-adult, and large juvenile striped bass $>20 \mathrm{~cm}$ Fork Length (FL) in Atlantic salmon supporting rivers (see Table 1). Locations numbered on the right panel (B) are studies conducted in the same region that were excluded from our analyses (see omitted studies in Table 1).

Dietary data were extracted from the eight remaining studies and expressed as the frequency of prey (by species) occurrence in stomachs containing food items (Table 2). Frequency of occurrence measures the number of stomachs containing each prey type (species) instead of counting the total abundance of each prey type across all stomachs. Enumerative methods that count each occurrence of each prey type to express dietary proportions (e.g., [22]) risk obscuring the prevalence of individual species of interest or rare species when large numbers of more abundant prey items are present leading to a misrepresentation of diet composition [41,42]. Enumerative methods also fail to account for or misrepresent actual predation rates where the number of predators encountering and predating a specific prey are of interest rather than the proportion of that prey species amongst other dietary items. High frequencies of occurrence may indicate that a prey is utilized by a large proportion of predators, whereas low frequency suggests infrequent predation by a small number of predators [41]. 
Table 1. Striped bass dietary studies for large adults, sub adults, and large juveniles $>20 \mathrm{~cm}$ Fork Length (FL) occurring within rivers supporting Atlantic salmon. The number of striped bass stomachs sampled $(n=5160)$, number and proportion of full stomachs $(n=1490 ; 0.16-0.75)$, collection methods and details, as well as primary food are described. The size ranges of the sampled striped bass are reported from each study as either fork length (FL), total length (TL) or kg. Map numbers (\#) match sampling locations illustrated in Figure 1.

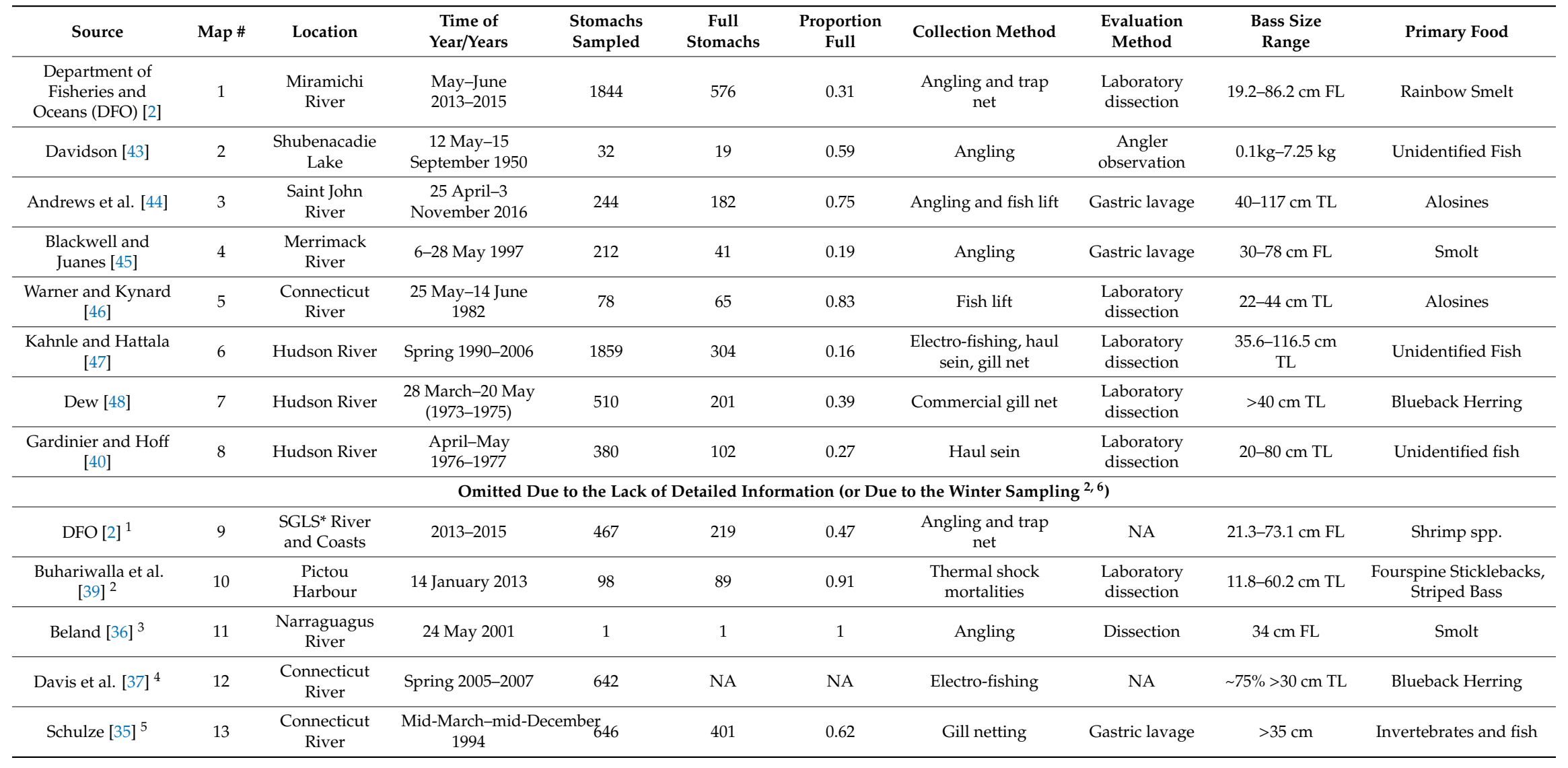


Table 1. Cont.

\begin{tabular}{|c|c|c|c|c|c|c|c|c|c|c|}
\hline Source & Map \# & Location & $\begin{array}{c}\text { Time of } \\
\text { Year/Years }\end{array}$ & $\begin{array}{c}\text { Stomachs } \\
\text { Sampled }\end{array}$ & $\begin{array}{c}\text { Full } \\
\text { Stomachs }\end{array}$ & $\begin{array}{l}\text { Proportion } \\
\text { Full }\end{array}$ & Collection Method & $\begin{array}{c}\text { Evaluation } \\
\text { Method }\end{array}$ & $\begin{array}{c}\text { Bass Size } \\
\text { Range }\end{array}$ & Primary Food \\
\hline Dunning et al. $[38]^{6}$ & 14 & Hudson River & Winter 1986-1994 & 1703 & 814 & 0.48 & Trawl & $\begin{array}{l}\text { Laboratory } \\
\text { dissection }\end{array}$ & $8.8-66.8 \mathrm{~cm} \mathrm{TL}$ & Crangon spp. \\
\hline $\begin{array}{c}\text { Gardinier and Hoff } \\
{[40]^{7}}\end{array}$ & 8 & Hudson River & $\begin{array}{c}\text { April-November } \\
1974\end{array}$ & 13 & NA & NA & $\begin{array}{l}\text { Beach sein, bottom } \\
\text { trawl }\end{array}$ & $\begin{array}{l}\text { Laboratory } \\
\text { dissection }\end{array}$ & $20.1-27.5 \mathrm{~cm} \mathrm{TL}$ & $\begin{array}{c}\text { Atlantic Tomcod, } \\
\text { Clupeids, White Perch }\end{array}$ \\
\hline
\end{tabular}

${ }^{1}$ Department of Fisheries and Oceans (DFO) [2] (secondary study) provides little information on capture locations or prey species, much of the sampling was coastal and smolt would have

been unavailable- one parr observed in a striped bass sampled from the Margaree River, N.S. ${ }^{2}$ Buhariwalla et al. [39] conducted sampling in winter when smolt would not be present- no smolt observed. ${ }^{3}$ Beland's [36] study was a single observation, not a diet study and, therefore, ratios of prey in diets cannot be determined—one smolt observed. ${ }^{4}$ Davis et al. [37] only reported consumption of blueback herring — no smolt reported. ${ }^{5}$ Schulze [35] did not identify prey to species—no smolt reported. ${ }^{6}$ Dunning et al. [38] conducted all sampling during winter—no smolt observed. ${ }^{7}$ Gardinier and Hoff [40] sampled 13 striped bass $>20 \mathrm{~cm}$ but reported stomach fullness collectively with samples from smaller striped bass—-no smolts observed. * Southern Gulf of Saint Lawrence (SGSL). 
Table 2. Number of sampled striped bass stomachs containing each prey type and the frequency of occurrence of each prey type amongst full stomachs $(n=1490)$. These frequencies were compiled from eight studies of adult, sub-adult, and juvenile striped bass $>20 \mathrm{~cm}$ Fork Length (FL) totaling 5160 sampled stomachs from rivers supporting Atlantic salmon (see Table 1; refer to Figure 1 for study locations).

\begin{tabular}{|c|c|c|}
\hline Prey Items & $\begin{array}{l}\text { Number of Stomachs } \\
\text { Containing Prey/1490 }\end{array}$ & Frequency of Occurrence \\
\hline Rainbow Smelt (Osmerus mordax) & 357 & 0.240 \\
\hline Unidentified Alosines (A1) & 247 & 0.166 \\
\hline Alewife (Alosa pseudoharengus) (A2) & 122 & 0.082 \\
\hline White perch (Morone americanus) & 52 & 0.035 \\
\hline Blueback Herring (Alosa aestivalis) (A3) & 51 & 0.034 \\
\hline Atlantic salmon (Salmo salar) & 48 & 0.032 \\
\hline American Eel (Anguilla rostrata) & 21 & 0.014 \\
\hline Yellow Perch (Perca flavescens) & 18 & 0.012 \\
\hline Atlantic Menhadden (Brevoortia tyrannus) & 17 & 0.011 \\
\hline American Sandlance (Amodytes americanus) & 15 & 0.010 \\
\hline Atlantic Tomcod (Microgadus tomcod) & 9 & 0.006 \\
\hline Sea Lamprey (Petromyzon marinus) & 9 & 0.006 \\
\hline Spottail Shiner (Notropis hudsonius) & 7 & 0.005 \\
\hline Brown Bullhead (Ameiurus nebulosus) & 3 & 0.002 \\
\hline Flatfish (Pleuronectidae sp.) & 3 & 0.002 \\
\hline Needlefish (Belonidae sp.) & 3 & 0.002 \\
\hline Anchovy (Anchoa mitchilli) & 2 & 0.001 \\
\hline Northern Pipefish (Syngnathus fuscus) & 2 & 0.001 \\
\hline Moronidae (sp.) & 2 & 0.001 \\
\hline American Shad (Alosa sapidissima) (A4) & 2 & 0.001 \\
\hline White Sucker (Catostomus commersonii) & 2 & 0.001 \\
\hline White Bullhead (Ictalurus catus) & 1 & 0.001 \\
\hline Cunner (Tautogolabrus adspersus) & 1 & 0.001 \\
\hline Striped Bass (Morone saxatilis) & 1 & 0.001 \\
\hline Atlantic Mackerel (Scomber scombrus) & 1 & 0.001 \\
\hline Unidentified fish * & 280 & 0.188 \\
\hline Non-salmonid Unidentified fish & 89 & 0.060 \\
\hline Total Alosines (sum A1-A4) & 422 & 0.283 \\
\hline Fishes (total) & 1365 & 0.916 \\
\hline Unidentified invertebrates & 90 & 0.060 \\
\hline Insects & 49 & 0.033 \\
\hline Crustaceans & 44 & 0.030 \\
\hline Blue Crab (Callinectes sapidus) & 41 & 0.028 \\
\hline Crangon (sp.) & 38 & 0.026 \\
\hline Isopods & 35 & 0.023 \\
\hline Unidentified crabs & 10 & 0.007 \\
\hline Nematodes & 11 & 0.007 \\
\hline Amphipods & 7 & 0.005 \\
\hline Gammarus (spp.) & 4 & 0.003 \\
\hline Polychaetes & 5 & 0.003 \\
\hline Squid & 3 & 0.002 \\
\hline Mud Crab (Rhithropanopeus harrisii) & 2 & 0.001 \\
\hline Total Invertebrates & 339 & 0.228 \\
\hline
\end{tabular}

* Unidentified fish may include Atlantic salmon smolt and alosines. The frequency of occurrence of Atlantic salmon smolts amongst all sampled striped bass stomachs was $48 / 5160=0.009$, i.e., $0.9 \%$ of all sampled striped bass had consumed one or more smolt. 


\subsection{Striped Bass Prey Size Selection, Gape Size Limitations, and Smolt Vulnerability}

Prey selection by striped bass is influenced both by body size [49] and gape size limitations [50]. Predator size, however, does not scale evenly with prey size selection and larger predators eat both small and large prey $[44,51]$. Large striped bass may consume smaller prey due to the higher encounter rate and ease of capture [51] in addition to large prey [47]. Smaller striped bass are more limited in the size and species they can consume due to their own physical size. Manooch [33] documented that striped bass consume clupeid prey up to $60 \%$ of their body length, but the average prey measured $\sim 20 \%$ of bass length.

Smolts originating from the Miramichi River range in size from 11-24 cm FL [34,52]. Based on Manooch [33], a striped bass must be at minimum 18-40 cm FL to predate smolt on the Miramichi River. DFO [22] indicated that striped bass on the Miramichi that consumed smolt were 32.6-62.5 (Scott Douglas, DFO Gulf Region, personal communication) despite sampled striped bass $(n=1844)$ ranging 19.2-86.2 cm FL. Blackwell and Juanes [45] and Beland et al. [36] reported that striped bass consuming smolt were $30-78 \mathrm{~cm}$ and $34 \mathrm{~cm}$ FL on the Merrimack and Narraguagus Rivers, respectively. These data collectively suggest the smolt vulnerability should be assessed using a minimum threat size for striped bass $\geq 30 \mathrm{~cm}$ FL.

\subsection{Feeding Behavior of Striped Bass During the Pre-Spawn, Spawn, and Post-Spawn Periods}

Striped bass spawning locations range from just upstream of the head of tide [53] to $\sim 200 \mathrm{~km}$ upstream from the river mouth (e.g., Roanoke River, North Carolina; [54]). Spawning occurs from mid-May to mid-June at water temperatures $>14.4{ }^{\circ} \mathrm{C}$ with peak egg production occurring from 15.6-19.4 ${ }^{\circ} \mathrm{C}$ [55]. The spawning period generally lasts $1-2$ weeks [56,57], can have multiple spawning peaks [56], and male striped bass may occupy spawning grounds longer than female striped bass [57].

Pre-spawn, adult striped bass typically move upstream to stage within the spawning river at or close to their spawning grounds in fresh or mesohaline waters [58,59]. They feed heavily during the upstream migration [60] and may continue to feed actively $[40,60,61]$ or at a reduced rate $[22,58,62]$ as the spawning period approaches. During the pre-spawn period striped bass diets often consist of other anadromous species with overlapping, upstream spawning migrations, e.g., blueback herring (Alosa aestivalis) [37], American Shad (Alosa sapidissima) [49], Rainbow Smelt [22], and Alewife (Alosa pseudoharengus) [44].

Feeding declines leading up to spawning $[58,63]$ and feeding ceases completely directly before and during spawning $[6,22,25]$. In an early study from the west coast, Scofield [61] reported finding prey in stomachs during the striped bass spawning period, but Raney [64] pointed out that the spawning state of striped bass sampled by Scofield [61] was never evaluated, i.e., sampled fish may not have been mature. Morgan and Gerlach [65] observed no food in the stomachs of female striped bass in spawning conditions in Coos Bay, Oregon, but males at all states of maturity were found to contain food. Striped bass resume feeding immediately post-spawn [65], however, the adult population typically moves rapidly downstream to estuarine or coastal habitats [66] where most feeding has been reported [22,67].

\subsection{Documented Predation by Striped Bass on Atlantic Salmon Smolts}

Few striped bass diet studies have documented predation on Atlantic salmon smolt. Only Blackwell and Juanes [49], Beland et al. [36], and the DFO [22] made direct observations of Atlantic salmon juveniles (smolt and/or parr) in the diet of striped bass (in the Merrimack, Narraguagus, and Miramichi rivers, respectively).

2.3.1. Blackwell and Juanes 1998: Predation on Atlantic Salmon Smolts by Striped Bass after Dam Passage [45]

Blackwell and Juanes [45] conducted the first diet-based study to raise concerns about striped bass impacts on Atlantic salmon. They sampled 212 striped bass stomachs below the Essex Dam on 
the Merrimack River in 1997 (Figure 1, Site 4). Only 19\% ( $n=41)$ of stomachs contained food items and 70 food items were reported. Of the consumed prey, $46 \%(n=32)$ were Atlantic salmon smolt and an additional $40 \%(n=28)$ were suspected to be smolt. The remaining $14 \%$ of prey were $(n=10)$ were blueback herring, sea lamprey (Petromyzon marinus), and other unidentified non-salmonids.

The contribution of Atlantic salmon smolts to the diet of striped bass in Blackwell and Juanes [45] may have been significantly affected by the smolt stocking program and overall state of diadromous fish populations of the Merrimack River at that time. The study was conducted in 1997 when only 403 river herring returned to the Essex Dam fish lift (J. McKeon, US Fish and Wildlife Service, personal communication). Concurrently, 1.8 million juvenile salmon, including 50,000 smolts were stocked to the Merrimack in 1996; 2 million juvenile salmon, including 57,800 smolts were stocked in 1997, and stocking had operated at a similar intensity for at least ten years prior [12]. Blackwell and Juanes [45] stated that all predated smolts to which an origin could be assigned were stocked as fry or smolt. Given the substantial number of stocked smolts and minimal returns of river herring, it is difficult to conclude that the observed striped bass diet in the Merrimack River in 1997 is a true reflection of smolt predation rates under natural river conditions or in other rivers.

Blackwell and Juanes [45] also employed angling to sample striped bass which could have introduced sampling bias due to the gut evacuation during sampling [68] and through the use of lures that resembled smolts [69]. Additionally, the Merrimack River does not support a spawning striped bass population [45] and it is unknown why striped bass entered the river. Elsewhere, non-spawning striped bass enter rivers during spring (i.e., when smolts would be present) to feed [70]. In the Merrimack River study, the proportion of striped bass observed with food in their stomachs (19\%) was low among diet studies for the species (range 17-98\%; [71]; Table 1, Table A1). The striped bass in the Merrimack River were most probably following the alosine migration upriver or were continuing a learned behavior from times when alosines were abundant (J. McKeon, US Fish and Wildlife Service, personal communication) because these are their preferred prey (Table 2, and see also References $[37,44])$. With low alosine numbers, the abundance of stocked smolts would produce a high potential striped bass encounter rate on smolts with little alternative prey. Because of the 1997 situation and the lack of additional methodological considerations (e.g., efficiency of gastric lavage), it is challenging to accurately assess the true smolt consumption rates by striped bass and the applicability of the results across the overlapping range of the two species.

\subsubsection{Beland et al. 2001: Striped Bass Predation upon Atlantic Salmon Smolt in Maine [36]}

Beland et al. [36] documented the consumption of a single, wild Atlantic salmon smolt $(18 \mathrm{~cm})$ by an immature striped bass (34 cm FL) on the Narraguagus River, Maine in 1996 (Figure 1, Site 11). Beland et al. [36] recounts how an acoustic signal corresponding to a tagged smolt was suddenly lost when an angler landed a striped bass. This observation was then confirmed via examination of the captured striped bass' stomach contents. The study presented no further evidence of smolt predation and evaluated no additional striped bass stomachs.

2.3.3. DFO 2015: Spawner Abundance and Biological Characteristics of Striped Bass (Morone Saxatilis) in the Southern Gulf of St. Lawrence in 2015 [22]

The Department of Fisheries and Oceans (DFO) [22] sampled 1844 striped bass stomachs ( 200$)$ from 1 May to 9 June in each of 2013-2015 by means of angling and commercial alewife fishers (trap nets). Among those striped bass sampled, 32\% $(n=587)$ of stomachs contained prey. Five percent $(n=28)$ of the striped bass with prey had consumed smolt, and these 28 individuals collectively consumed 48 smolt (Scott Douglas, DFO Gulf Region, personal communication). In a secondary study, DFO [22] sampled 467 striped bass (21.3-73.1 cm FL) in unspecified locations throughout the Southern Gulf of Saint Lawrence, Miramichi River, NB and Margaree River, NS using angling, index trap nets, and commercial alewife trap nets from 2013-2015. A single Atlantic salmon parr was observed in one striped bass stomach collected from the Margaree River in 2014. 
Striped bass and Atlantic salmon in the Miramichi River and its estuary use the two main branches of the river, the Southwest Miramichi (SW) and Northwest Miramichi (NW). Most striped bass spawning has been reported from the NW [32]. DFO [22] sampled 1407 striped bass (76\%) from the NW, $114(6 \%)$ from the SW, and $298(16 \%)$ from the main river downstream of both branches (estuarine portion of the river). In addition, 25 striped bass (1\%) were either sampled from the NW or the main river during an angling derby. Smolt outmigration numbers for the Miramichi River system tallied 25-35\% for the NW and 65-75\% for the SW [54]. Such differences in the behavior and habitats of striped bass and Atlantic salmon smolt (between the NW and SW) are important factors when investigating total predation, e.g., smolt numbers were greatest in the SW where striped bass spawning is limited [24].

More than half $(54 \%)$ of the 48 predated smolt $(n=26)$ in the DFO (2016) study [22] were collected in 10 striped bass stomachs from one location (mouth of Northwest Millstream, a tributary of the NW). This prevalence of smolt-containing stomachs from one location could bias total predation rate estimates if extrapolated for the entire river. For example, differences in the frequency of smolt occurrence in striped bass stomachs between Millstream on the NW (19\%) and elsewhere (3\%) suggest differential predation rates, i.e., a "predation hot spot" in the Millstream vicinity [72,73].

Sampling methodology can also introduce bias and 54\% of sampled striped bass spent approximately $24 \mathrm{~h}$ in trap nets prior to gut evacuation [22]. There would have been limited to no access to smolts inside the trap nets and gut evacuation rates at ambient river temperatures are unclear (evacuation of tags by striped bass from tagged prey is $1.2-2.7$ days at $23.3^{\circ} \mathrm{C}$; [74]). Striped bass also feed differentially depending on maturity and spawning state (e.g., [40,60]). The sampled striped bass were 19.2-86.2 cm FL and smolts occurred in striped bass 32.6-62.5 cm FL (Scott Douglas, DFO Gulf Region, personal communication). These results are consistent with other reports that suggest prey utilization varies among size and maturity states for striped bass (e.g., $[40,75]$ ).

DFO [22] identified an unknown number (described as "many") of the 48 predated smolt based on the occurrence of otoliths in stomach contents of the striped bass. Identifying fish species in diets using otoliths is possible [76], but it can be complicated as otoliths are subject to erosion in the gut [77,78]. Identifying otoliths in diet studies requires protocols that include reference collections and/or atlases to address otolith erosion and double counting [77,79]. For example, DFO [22] reports stomachs with $>1$ smolt based on otolith counts but there are three pairs of otoliths per smolt. The residency time of otoliths in striped bass stomachs is also unknown leading to uncertainties regarding smolt origin from either within or exterior to the Miramichi River.

It should be noted within the context of the DFO [22] study, that the objective of the study appears to be the documentation of striped bass diet during their residence in the Miramichi River for spawning. This is very different from a study design that would assess whether striped bass predation affects the declining Atlantic salmon population. This is an important distinction because while DFO [22] reports that smolt contribute to the overall striped bass diet in what can be considered a relatively small proportion, the study cannot address whether the documented removal rate of smolt has an affect on the adult Atlantic salmon population that would be of management concern. To address the question regarding the potential affect, a future study would have to be directly designed to look into that specific question.

\subsection{Assessment of Smolt Predation by Acoustic Tagging}

The remaining two studies we assessed $[20,80]$ used an analysis of acoustically tagged Atlantic salmon smolt to indicate predation events by striped bass (Figure 2). 


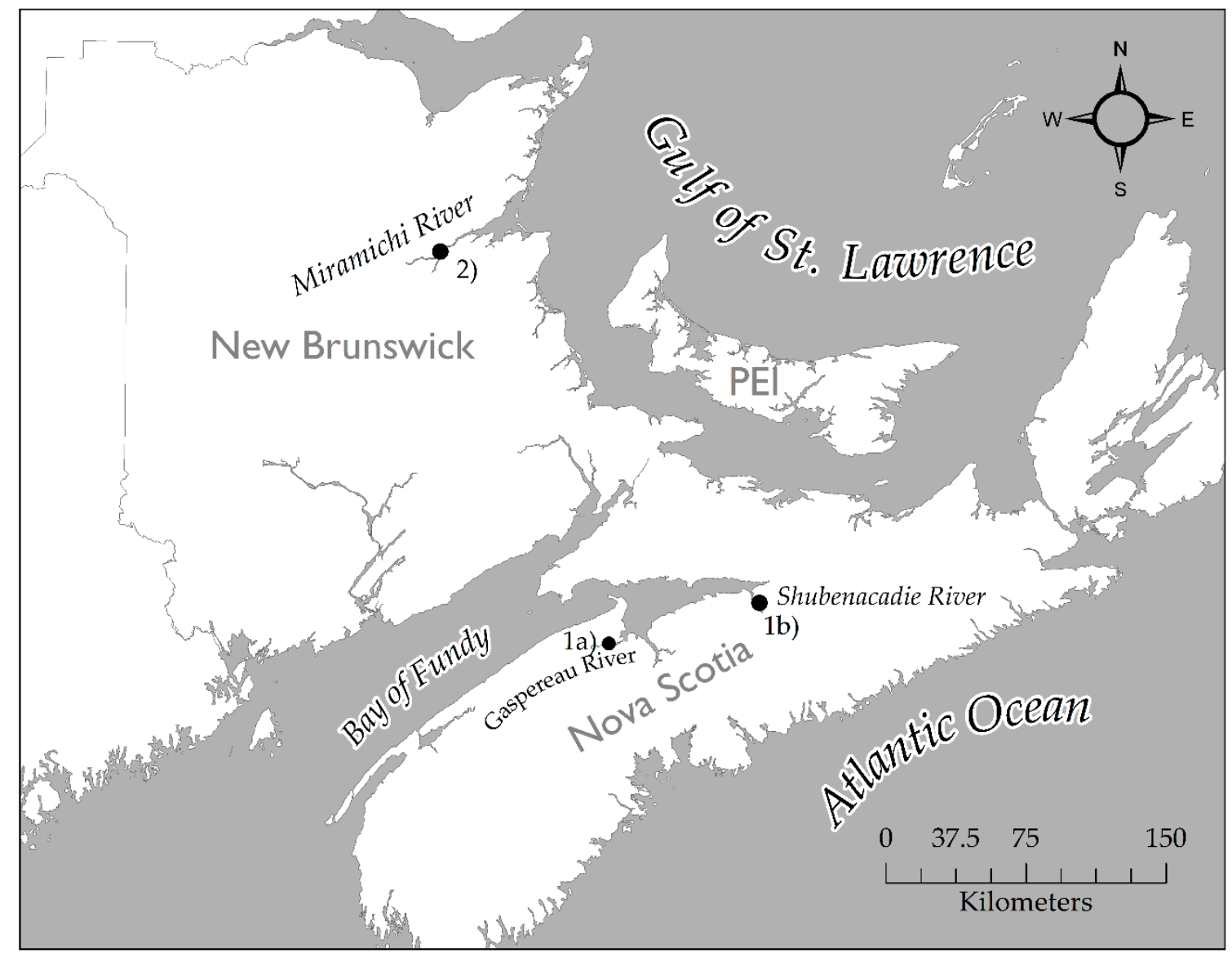

Figure 2. Location of the smolt/striped bass tracking studies conducted by Gibson et al. [80] (1a, b), and Daniels et al. [20] (2) on the Gaspereau/Shubenacadie and Miramichi Rivers, respectively.

2.4.1. Gibson et al. 2015: Effects of Predation on Telemetry-based Estimates: Insights from a Study on Endangered Atlantic Salmon Smolts [80]

Gibson et al. [80] released 93 acoustically tagged "wild acclimated" hatchery origin smolt (originally released as fry) into the Stewiacke River, NS during $2008(n=66)$ and $2011(n=27)$, and released 20 tagged smolts into the Gaspereau River, NS in 2011 (Figure 2). Striped bass $(n=31 ; \mathrm{TL}=41-89.9 \mathrm{~cm}$ ) were captured in 2008 and $(n=13 ; \mathrm{TL}=54.5-78.0)$ in 2011 in a trap net and tagged with acoustic tags in the upper Shubenacadie River [81] as they exited their overwintering habitat in a large headwater lake. Using cluster analyses based on presumed migration metrics of both species, the study described 2.4-13.6\% of smolt movement patterns being most like those of striped bass in the Stewiacke and Gaspereau Rivers across study years. These movement patterns, along with losses of tagged smolt suggested that striped bass predation could have accounted for $7 \%$ and $27 \%$ of total smolt mortality on the Shubenacadie River in 2008 and 2011, respectively.

The presented results are not a direct measure of predation on wild Atlantic salmon smolt and introduce several biases that could inflate predation rate predictions. The study discussed post-tagging survival but overlooked tag:smolt-length ratios and their impact on smolt behavior (e.g., [82,83]). The tags employed in the study were Vemco V9-6L ( $\mathrm{W}=2.9 \mathrm{~g}, \mathrm{~L}=24 \mathrm{~mm})$, representing $3.2-14.4 \%$ of smolt body weight (range 20-90 g) and 11.4-20.0\% of smolt body length (range 120-210 mm FL), exceeding the $8 \%$ body weight and $16 \%$ body length limits recommended by Lacroix et al. [82], who reported that exceedances significantly impaired the swimming speed of Atlantic salmon juveniles for up to seven days post-tagging. Also, Collins et al. [84] demonstrated that surgical tagging can reduce the average swimming duration for sockeye salmon smolts (Oncorhynchus nerka) of similar size. Mortalities attributed to tag size or behavioral consequences suffered by the Atlantic salmon smolt in 
Gibson et al. [80] may be reflected in the post-release tagging mortality rates that were $25 \%(5 / 20)$ in the Gaspereau River and 32\% (30/93) in the Stewiacke River. Furthermore, there is no accounting of differential predation rates on tagged versus untagged smolt [82,85].

2.4.2. Daniels et al. 2018: Estimating Consumption Rate of Atlantic Salmon Smolts (Salmo salar) by Striped Bass (Morone saxatilis) in the Miramichi River Estuary Using Acoustic Telemetry [20]

Daniels et al. [20] monitored acoustically tagged striped bass and Atlantic salmon smolt on the Miramichi River (Figure 2, Site 1), based closely on the method of Gibson et al. [80]. From 2013-2016, 514 smolts (12.1-18.2 cm FL) were acoustically tagged within the SW and NW branches of the Miramichi River (captured in smolt wheels). In the summer and fall of 2013, 50 striped bass (body sizes were unreported) were angled and tagged in the Bay of Chaleur and 40 striped bass (45.6-73.5 cm FL) were tagged from a DFO index trap net on the SW Miramichi River. Transmitter detections in the Miramichi River were provided by 19 receivers over four years (seven in the NW, five in the SW, and seven in the main river estuary). A random forest model (description in Daniels et al., [20]) was constructed to differentiate predator and prey movements according to eight criteria chosen by the authors. Predation events were based on a binary classification scheme for movement patterns where paths were either "bass like" or "smolt like". Daniels et al. [20] inferred through tag movements that 2-18\% of tagged smolts were predated by striped bass annually over a period of four years and specifically, 7-20\% of NW origin smolt, and $2-17 \%$ of SW origin smolts. The locations of smolt predation were not differentiated between the NW/SW branches and the main stem (downstream of confluence).

\subsubsection{Considerations for Acoustic Predation Assessment}

Both Daniels et al. [20] and Gibson et al. [80] have several additional caveats that potentially affected their reported predation rates. Both studies tracked striped bass $>40 \mathrm{~cm}$, yet it is likely that the "threat size" begins at $>30 \mathrm{~cm}$. Describing smolts' movement patterns by transmitter detections at fixed receivers with low spatial coverage i.e., gaps up to $27 \mathrm{~km}$ between receivers (e.g., Daniels et al. [20]) and without assessing tagging effects on smolt survival and behavior [82] or detection efficiencies of the fixed receivers can introduce unknown variability in detection rates and, thus, interpretations. For example, detections are predicted to be highly variable in the downstream reaches of the Miramichi River because of its channel and tidal conditions which alter detection rates [86,87]. Also missing is the separation of tagged striped bass among maturity state and pre-, during, and post-spawning activities which affect feeding in striped bass (e.g., [60])

Designating tag behavior as "bass like" also has its limitations in estuaries where multiple smolt predators exist, for example in the Miramichi River where anadromous brook trout (Salvelinus fontinalis), adult salmon returning to the sea (i.e., kelts), and seals (e.g., Halichoerus grypus) are also present and potentially consume smolt.

\section{Discussion}

While predation can be a significant driver of fish community structure [88,89], many biotic and abiotic factors regulate the population dynamics of both predators and their prey. In large, complex, and dynamic estuarine ecosystems where striped bass and Atlantic salmon co-occur, like the Miramichi River, quantifying predation and assessing its risk will require the integration of spatial and temporal variables that have the potential to regulate both prey and predators (e.g., [90,91]). For example, in the Miramichi River, the spatial and temporal overlap of the striped bass and Atlantic salmon smolt has received limited study, but these factors are important because they dictate encounter rates, times, and locations. In the Miramichi River, smolt out-migration also overlaps with rainbow smelt, alewife, blueback herring, American shad, and potentially American eel elvers, which are all important foods of striped bass. Other predators may affect predation rates in the Miramichi River, in addition to commercial fishing operations for alewife and smelt which serve as key alternative prey. Assessing 
predation in a complex system requires planning and most probably several years to capture the temporal variability among all the relevant factors.

In addition, acoustic tracking data must be interpreted carefully to provide meaningful biological synthesis. Tagged fish may experience mortality and behave differentially after tagging (e.g., [82]) which can alter their survival outcomes and predation susceptibility relative to their untagged counterparts [83]. Fixed receivers have tag detection effectiveness determined by tag-receiver connectivity which is a function of many variables, associated with tags, fish behavior, and environmental conditions [92,93]. Receivers always require testing to determine efficiencies for inclusion in movement models [93].

Studying smolt predation by any predator is inherently complex in nature simply due to the brevity of the smolt migration (i.e., typically less than 4 weeks with the bulk of the smolt migration focused within a few days). This brief time period is rarely conducive to extensive sampling protocols either temporally or spatially rendering most study designs inadequate for the accurate evaluation of predation impacts. Smolt tagging studies likely offer the best and perhaps the only chance to quantify predation during this period but only under the following circumstances: (1) physical and temporal tagging impacts (i.e., swimming impairment and migration delay) must be minimized and tagged smolt must adequately reflect the diversity in size and migratory timing of untagged individuals, and these requirements would likely be achieved through tagging smolt in the fall preceding spring migration; (2) alternative prey abundance during the smolt migration window should be assessed through routine sampling which would separate instances of high smolt predation from low occurrence of alternate forage; (3) the location of predation events of tagged smolt should be compared to the regional and temporal abundance of predators, either from predator tagging or sonar surveys to identify if areas of vulnerability correspond with those of high predator abundance or other riverine features; (4) caveats of tagging (e.g., tag size impacts, delayed release, tagging recovery periods, non-predation mortality) must be clearly outlined by the authors and identified as factors that could result in tagged smolt being less or more susceptible to predation, thus potentially impacting results; and (5) the study should be repeated over multiple years and the results should be compared to smolt escapement, predator abundance and size distribution, as well as subsequent adult salmon returns. Documented predation rates may be inconsequential unless their impact on adult salmon spawner abundance can be demonstrated. Without these considerations, smolt tracking studies may easily overlook critical factors such as predator hot spots or increased prey vulnerability, and may incorrectly assume predation or even high predation across a population or region.

When performing a diet-based analysis of smolt predation, investigators should increase the detail of their reporting, especially when lethal samples are collected. Information on the frequency of occurrence of all prey items, smolt size, predator size, sex and state of maturity, sampling location, sampling time (e.g., hour, day/night) and method of collection should all be reported. These data must also be complemented by a clear delineation of the smolt run timing in the reported sampling season, some measure of the occurrence or abundance of alternative prey species and would benefit greatly from monitoring predator movements through acoustic tagging or sonar survey evaluation. Efforts must also be made to sample a diversity of areas and times and not simply those when predators are most easily captured. The effects of capture method and gear type must also be carefully considered. Diet evaluation studies, however, inevitably risk greatly over or underestimating true predation rates through over or under sampling predation hotspots, especially when predation rates are low. Consequently, diet studies may be best utilized only to identify timing of predation, predation hotspots, predator threat size, and prey size vulnerability, and not to estimate predation rates which may be easily confused with simple diet composition (i.e., prey accessibility/availability and sampling method/location influencing frequency of occurrence). This is especially true when local predator and target prey abundance are unknown during the rapid aggregation and dispersal period associated with spring migrations and spawning.

Additional missing information that could benefit the analysis of striped bass predation on smolt includes: (1) an investigation of striped bass prey digestion rates and residency time of structures or 
materials commonly used for prey identification (i.e., otoliths, scales, bones or DNA) in striped bass stomachs, (2) fine scale tracking of predators and prey to determine temporal habitat overlap, and (3) a measurement of adult salmon returns prior to and following documenting levels of smolt predation. More detailed reporting on prey and predator length may further aid in identifying prey vulnerability and predator threat sizes that could be more effectively managed by directed fisheries if necessary.

\section{Summary}

Few existing studies of striped bass predation on Atlantic salmon smolt collectively provide uncertain interpretations of species interactions and the potential for impacts on salmon populations. Three studies $[22,36,45]$ directly confirm smolt in striped bass stomachs which demonstrate that predation can and does occur. While studies such as the one conducted by the DFO [22] are extensive, they are difficult to interpret because their analyses often overlook complexities associated with methodologies like stomach content analyses and sampling designs (e.g., locations and timing). In addition, there has been no comprehensive study of how predation is effected by the abundance and behavior of prey, other predators, environmental variables (e.g., physical river characteristics, water temperature, tide, light conditions), and the spatiotemporal variation underlying each of these factors. Many of these factors drive or influence the number of smolt observed in striped bass diets and, importantly, total smolt mortality attributed to striped bass predation. Two additional studies $[20,80]$ inferred smolt predation through detections of tagged predators and prey but the biotelemetry techniques used to develop the inferences must be interpreted carefully.

In the future, it is important to focus on designing studies with clear objectives and to differentiate between objectives geared towards documenting the diet of a predator or assessing what impact observed predation levels may be having on a target prey population. This distinction is especially true for the Miramichi River, where a relatively abundant predator may be interacting with a declining prey. An accurate estimate of striped bass predation on Atlantic salmon smolt within a river requires a comprehensive, ecosystem-scale approach. Only careful study of the ecosystem's predators and prey, their spatio-temporal distributions, overlap, behavioral interactions, and relevant environmental drivers will reveal the magnitude and scope of predation Atlantic salmon smolts.

Author Contributions: S.N.A. and S.V.H. compiled and reviewed predation literature and wrote the article, T.L. and R.A.C. provided feedback on ideas and direction and reviewed the article prior to submission.

Funding: Atlantic Salmon Conservation Foundation (ASCF) grant.

Acknowledgments: This article and its authors were funded in part by the Atlantic salmon Conservation Foundation, and NSERC. We would like to thank Scott Douglas from the Fisheries and Oceans Canada, Gulf Region for providing additional information on striped bass on the Miramichi and Bronwyn Fleet-Pardy for helping to produce maps in GIS.

Conflicts of Interest: The authors declare no conflict of interest. 


\section{Appendix A}

Table A1. Striped bass (Morone saxatilis) diet sampling conducted on age 0 and juvenile striped bass and striped bass in coastal or marine environments within the range of Atlantic salmon (Salmo salar). For each study itemized below, location and sampling date are provided including the size range of sampled fish, the number of samples taken, the number of stomachs containing food items, and the primary food items identified. Each study can also be located on Figure $1 \mathrm{~A}$ using the associated map numbers.

\begin{tabular}{|c|c|c|c|c|c|c|c|c|}
\hline Source & Map \# & Location & Time of Year/Years & $\begin{array}{l}\text { Size of Fish } \\
\text { Sampled } \\
(\mathrm{mm}) / \text { Age }\end{array}$ & $\begin{array}{l}\text { Stomachs } \\
\text { Sampled }\end{array}$ & $\begin{array}{c}\text { Full } \\
\text { Stomachs }\end{array}$ & $\begin{array}{l}\text { Proportion } \\
\quad \text { Full }\end{array}$ & Primary Food \\
\hline \multicolumn{9}{|c|}{ Age 0 and Juvenile Striped Bass Diet Sampling } \\
\hline $\begin{array}{l}\text { Robichaud-Leblanc } \\
\text { et al. [94] }\end{array}$ & 15 & Miramichi River & June-November 1992 & $2.9-153.3 \mathrm{~mm}$ & 2928 & 2247 & 0.76 & $\begin{array}{l}\text { Rotifers, Copepods, Mysids, } \\
\text { Crangon }\end{array}$ \\
\hline $\begin{array}{l}\text { Smircich et al. } \\
\text { [95] }\end{array}$ & 16 & Hudson River (near 96 km) & $\begin{array}{c}\text { Early } \\
\text { June-mid-September } \\
\text { 1988-2012 } \\
\end{array}$ & $6-60 \mathrm{~mm}$ & 840 & 642 & 0.76 & $\begin{array}{c}\text { Copepoda, Amphiods } \\
\text { (Gammardiae, Corophiidae) }\end{array}$ \\
\hline $\begin{array}{l}\text { Gardinier and } \\
\text { Hoff [40] }\end{array}$ & 17 & Hudson River (53-74 km) & April-November 1974 & $<76 \mathrm{~mm}$ & 501 & 422 & 0.82 & $\begin{array}{l}\text { Amphipods (Gammarus), } \\
\text { Copepods and Cladocerans }\end{array}$ \\
\hline- & - & - & - & $76-150 \mathrm{~mm}$ & - & - & & $\begin{array}{c}\text { Amphipods (Gammarus), Bay } \\
\text { Anchovy, Atlantic Tomcod, } \\
\text { Banded Killifish }\end{array}$ \\
\hline- & - & - & - & $151-200 \mathrm{~mm}$ & - & - & & $\begin{array}{l}\text { Blueback Herring, Bay } \\
\text { Anchovy, Atlantic Tomcod, } \\
\text { Banded Killifish, } \\
\text { Mummichog }\end{array}$ \\
\hline- & - & - & - & 201-275 mm & $13^{*}$ & - & & $\begin{array}{l}\text { Atlantic Tomcod, alosines, } \\
\text { White Perch, Striped Bass }\end{array}$ \\
\hline $\begin{array}{c}\text { Jordan and Juanes } \\
{[96]}\end{array}$ & 18 & Hudson River (35-70 km) & $\begin{array}{c}\text { July-November } \\
\text { 1994-1997 }\end{array}$ & $<50$ to $>100 \mathrm{~mm}$ & 695 & 576 & 0.82 & Amphipods \\
\hline $\begin{array}{l}\text { Howe and Juanes } \\
\text { [97] }\end{array}$ & 19 & Hudson River (32-72 km) & $\begin{array}{l}\text { Mid-July to early } \\
\text { November } 1998\end{array}$ & $57.3 \pm 10.9 \mathrm{~mm}$ & 254 & 231 & 0.91 & Amphipods \\
\hline Jordan et al. [98] & 20 & Hudson River (35-70 km) & $\begin{array}{c}\text { July-November } \\
\text { 1994-1997 }\end{array}$ & $<50$ to $>100 \mathrm{~mm}$ & $950 * *$ & 798 & 0.84 & Amphipods \\
\hline $\begin{array}{c}\text { Curran and Ries } \\
\text { [99] }\end{array}$ & 21 & Hudson River (Dennings Point) & 23 July-13 August & 30-110 mm & 105 & - & & $\begin{array}{l}\text { Amphipods (Gammarus), } \\
\text { Chronomids and Copepods }\end{array}$ \\
\hline \multirow[t]{2}{*}{$\begin{array}{l}\text { Buckel and } \\
\text { Mckown [100] }\end{array}$} & 22 & New York Bight & $\begin{array}{l}\text { May-November } \\
\text { 1997-1998 }\end{array}$ & $39-296 \mathrm{~mm}$ & 602 & 439 & 0.72 & Sand Shrimp (sp.) \\
\hline & & & Total & $2.9-296 \mathrm{~mm}$ & 6193 & 4779 & 0.77 & $77 \%$ full stomachs \\
\hline
\end{tabular}


Table A1. Cont.

\begin{tabular}{|c|c|c|c|c|c|c|c|c|}
\hline Source & Map \# & Location & Time of Year/Years & $\begin{array}{l}\text { Size of Fish } \\
\text { Sampled } \\
(\mathrm{mm}) / \text { Age }\end{array}$ & $\begin{array}{l}\text { Stomachs } \\
\text { Sampled }\end{array}$ & $\begin{array}{c}\text { Full } \\
\text { Stomachs }\end{array}$ & $\begin{array}{l}\text { Proportion } \\
\quad \text { Full }\end{array}$ & Primary Food \\
\hline \multicolumn{9}{|c|}{ Marine Striped Bass Diet Sampling } \\
\hline Melvin [101] & 23 & Kouchibuguac River & $\begin{array}{l}15 \text { June-1 November } \\
1978\end{array}$ & $27.4-54.6 \mathrm{~cm}$ & 255 & 179 & 0.70 & Sand Shrimp, Fundulus \\
\hline $\begin{array}{c}\text { Rulifson and } \\
\text { McKenna [102] }\end{array}$ & 24 & Minas Basin, Cobequid Bay & 1 June-18 October 1985 & $69-94 \mathrm{~mm}$ & 80 & 78 & 0.98 & Crangon septemspinosa \\
\hline Liem [103] & 25 & Bass River, Nova Scotia & NA & $\sim 20 \mathrm{~cm}$ & NA & NA & & Crangon \\
\hline Wilkinson [104] & 26 & Saco Bay, Maine & May-October 2011 & $43.4-59.9 \mathrm{~cm}$ & 57 & 43 & 0.75 & Sand Lance \\
\hline- & - & - & - & $60.0-74.9 \mathrm{~cm}$ & - & - & & Sand Lance \\
\hline- & - & - & - & $75.0-109.2 \mathrm{~cm}$ & - & - & & $\begin{array}{c}\text { Sand Lance, American } \\
\text { lobster }\end{array}$ \\
\hline $\begin{array}{c}\text { Ferry and Mather } \\
\text { [67] }\end{array}$ & 27 & Massachusetts estuaries & May-October 1999 & $37.5-47.5 \mathrm{~cm}$ & 797 & 677 & 0.85 & Alosines \\
\hline Nelson et al. [105] & 28 & Coastal Massachusetts & $\begin{array}{c}\text { June-September } \\
1997-2000\end{array}$ & $29.0-116.2 \mathrm{~cm}$ & 3006 & 1720 & 0.57 & $\begin{array}{l}\text { Crustaceans and Atlantic } \\
\text { Menhaden }\end{array}$ \\
\hline $\begin{array}{c}\text { Sagarese et al. } \\
{[106]}\end{array}$ & 29 & Long Island, New York & $\begin{array}{l}\text { May-October } \\
2007-2008\end{array}$ & $39.6-95.9 \mathrm{~cm}$ & 23 & 15 & 0.65 & $\begin{array}{l}\text { Sand Shrimp, Summer } \\
\text { Flounder }\end{array}$ \\
\hline Schaefer et al. [75] & 30 & Long Island, New York & $\begin{array}{l}27 \text { April-24 November } \\
1964\end{array}$ & $27.5-39.9 \mathrm{~cm}$ & 61 & 49 & 0.80 & Amphipods and mysids \\
\hline- & - & - & - & $40.0-59.9 \mathrm{~cm}$ & 183 & 145 & 0.79 & $\begin{array}{l}\text { Amphipods and Bay } \\
\text { Anchovy }\end{array}$ \\
\hline- & - & - & - & $60.0-94.0 \mathrm{~cm}$ & 123 & 28 & 0.22 & $\begin{array}{c}\text { Amphipods, Bay Anchovy, } \\
\text { and Squirrel Hake (Urophycis } \\
\text { chuss) }\end{array}$ \\
\hline- & - & - & - & $14.1-24.0 \mathrm{~cm}$ & - & - & & Crangon septemspinosa \\
\hline- & - & - & - & $27.1-36.0 \mathrm{~cm}$ & - & - & & $\begin{array}{l}\text { Crangon septemspinos, } \\
\text { Unidentified fish }\end{array}$ \\
\hline- & - & - & - & $38.1-44.0 \mathrm{~cm}$ & - & - & & $\begin{array}{l}\text { Crangon septemspinos, } \\
\text { Unidentified fish }\end{array}$ \\
\hline- & - & - & - & $48.1-52.0 \mathrm{~cm}$ & - & - & & Unidentified fish \\
\hline \multirow[t]{2}{*}{$\begin{array}{l}\text { Merriman [107] } \\
\quad 1941\end{array}$} & 31 & New Jersey, Massachusetts & $\begin{array}{l}\text { April-November } 1936 \\
\text { and } 1937\end{array}$ & $6.5-115 \mathrm{~cm}$ & 550 & 264 & 0.48 & $\begin{array}{l}\text { Atlantic Menhaden, Atlantic } \\
\text { Silverside }\end{array}$ \\
\hline & & & Total & $6.5-116.2 \mathrm{~cm}$ & 5135 & 3198 & 0.62 & $62 \%$ full stomachs \\
\hline
\end{tabular}

* Diets of 201-275 mm striped bass sampled by Gardinier and Hoff [40] were inseparable from that of smaller individuals. ${ }^{* *}$ Includes 695 samples from Jordan and Juanes [96]. 
Species reference: Banded Killifish (Fundulus diaphanus), Bay Anchovy (Anchoa mitchilli), Blueback Herring (Alosa aestivalis), Fourspine Stickleback (Apeltes quadracus), American Lobster (Homarus americanus), Mummichog (Fundulus heteroclitus), Atlantic Menhaden (Brevoortia tyrannus), Sand Lance (Ammodytes americanus), Sand Shrimp (Crangon septemspinosa), Atlnatic Silverside (Menidia menidia notata), Striped Bass (Morone saxatilis), Squirrel Hake (Urophycis chuss) Atlantic Tomcod (Microgadus tomcod), White Perch (Morone americanus).
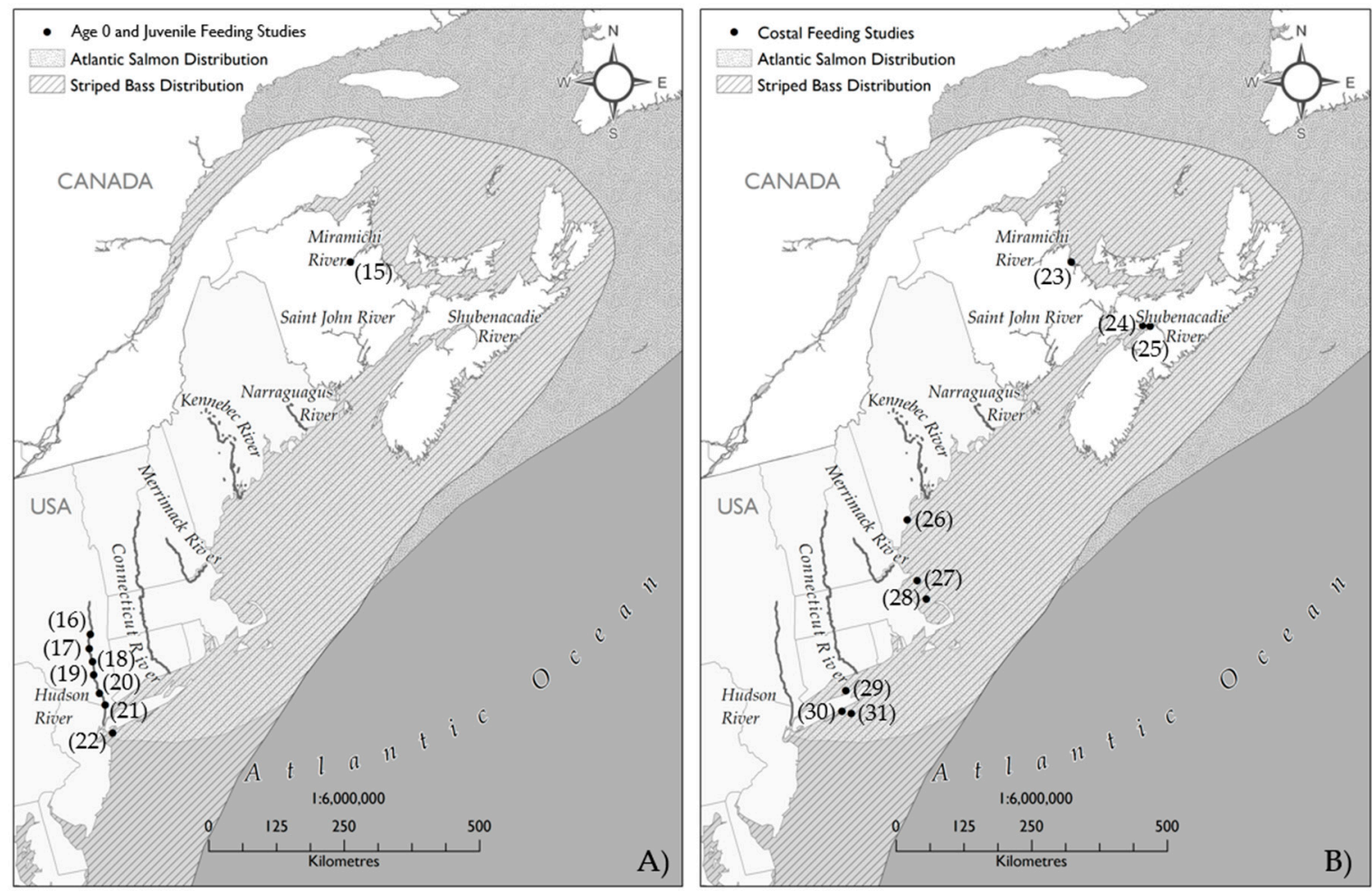

Figure A1. Map depicting the overlapping range of Atlantic salmon (grey, stippled region extending north) and striped bass (grey, striped region extending south) along the Atlantic Coast of the United States and Canada. The numbered points on the left panel (A) indicate the dietary studies conducted on age 0 and juvenile striped bass in Atlantic salmon supporting rivers (see Appendix A Table A1). Locations numbered on the right panel (B) are studies conducted on striped bass diet in marine and coastal environments across Atlantic salmon range (see Appendix A Table A1).

\section{References}

1. MacCrimmon, H.R.; Gots, B.L. World distribution of Atlantic Salmon, Salmo Salar. J. Fish. Res. Board Can. 1979, 36, 422-457. [CrossRef]

2. Scott, W.B.; Scott, M.G. Family Percichthyidae/Temperate Basses. In Atlantic Fishes of Canada; Canadian Bulletin of Fisheries and Aquatic Sciences 219; University of Toronto Press: Toronto, ON, Canada, 1988; pp. 356-360.

3. Tremblay, S.; Caron, F.; Groleau, C.; Deschamps, D. Bilan de L'exploitation du Saumon au Québec en 1998; Faune et Parcs Québec: Québec, QC, Canada, 1999.

4. World Wildlife Federation (WWF). The Status of Wild Atlantic Salmon: A River by River Assessment; WWF: Washington, DC, USA, 2001.

5. Rulifson, R.A.; Dadswell, M.J. Life history and population characteristics of Striped Bass in Atlantic Canada. Trans. Am. Fish. Soc. 1995, 124, 477-507. [CrossRef]

6. Greene, K.E.; Zimmerman, J.L.; Laney, R.W.; Thomas-Blate, J.C. Atlantic Coast Diadromous Fish Habitat: A Review of Utilization, Threats, Recommendations for Conservation, and Research Needs; Atlantic States Marine Fisheries Commission: Washington, DC, USA, 2009. 
7. Leblanc, N.M.; Andrews, S.N.; Avery, T.S.; Puncher, G.N.; Gahagan, B.I.; Whiteley, A.R.; Curry, R.A.; Pavey, S.A. Evidence of a Genetically Distinct population of Striped Bass in the Saint John River, New Brunswick, Canada. N. Am. J. Fish. Manag. 2018, 38, 1339-1349. [CrossRef]

8. Stolte, L. The Forgotten Salmon of the Merrimack; Department of the Interior: Washington, DC, USA, 1981.

9. Stolte, L.W. Atlantic Salmon restoration in the Merrimack River Basin. In A Hard Look at Some Tough Issues: New England Atlantic Salmon Management Conference, Proceedings of the New England Atlantic Salmon Management Conference, Danvers, MA, USA, 22-23 April 1994; Calibi, S., Stout, A., Eds.; New England Salmon Association: Newburyport, MA, USA, 1994.

10. Moring, J.R. Restoration of Atlantic Salmon to Maine: Overcoming physical and biological problems in the estuary. In Proceedings of the Coastal Zone '87: Fifth Symposium on Coastal and Ocean Management, Seattle, WA, USA, 26-29 May 1987; Magoon, O.T., Converse, H., Miner, D., Eds.; American Society of Civil Engineers: Seattle, WA, USA, 1987; pp. 3129-3140.

11. Meyers, T. The program to restore Atlantic salmon in the Connecticut River. In A Hard Look at Some Tough Issues: New England Atlantic Salmon Management Conference, Proceedings of the New England Atlantic Salmon Management Conference, Danvers, MA, USA, 22-23 April 1994; Calibi, S., Stout, A., Eds.; New England Salmon Association: Newburyport, MA, USA, 1994; pp. 11-21.

12. USASAC. Annual Report of the U. S. Atlantic Salmon Assessment Committee; Report No. 1-29; USASAC: Huntsville, AL, USA, 1989-2017.

13. Izzo, L.K.; Maynard, G.A.; Zydlewski, J. Upstream Movements of Atlantic Salmon in the lower Penobscot River, Maine Following Two Dam removals and Fish Passage Modifications. Mar. Coast. Fish. 2016, 8, 448-461. [CrossRef]

14. ICES. Report of the Working Group for North Atlantic Salmon (WGNAS); International Council for the Exploration of the Sea. Advisory Committee on Fisheries Management: Woods Hole, MA, USA, 2018.

15. COSEWIC. COSEWIC Assessment and Status Report on the Atlantic Salmon Salmo Salar (Nunavik Population, Labrador Population, Northeast Newfoundland Population, South Newfoundland Population, Southwest Newfoundland Population, Northwest Newfoundland Population, Quebec Eastern North Shore Population, Quebec Western North Shore Population, Anticosti Island Population, Inner St. Lawrence Population, Lake Ontario Population, Gaspé-Southern Gulf of St. Lawrence Population, Eastern Cape Breton Population, Nova Scotia Southern Upland Population, Inner Bay of Fundy Population, Outer Bay of Fundy Population) in Canada; Committee on the Status of Endangered Wildlife in Canada: Ottawa, ON, Canada, 2010.

16. Fay, C.; Bartron, M.; Craig, S.; Hecht, A.; Pruden, J.; Saunders, R.; Sheehan, T.; Trial, J. Status Review for Anadromous Atlantic SALMON (Salmo Salar) in the United States; United States Fish and Wildlife Service: Washington, DC, USA, 2006.

17. DFO. Update of Indicators of Atlantic Salmon (Salmo Salar) in DFO Gulf Region Salmon Fishing Areas 15-18 for 2016; Fisheries and Oceans Canada: Ottawa, ON, Canada, 2017.

18. McGinnity, P.; Prodöhl, P.; Ferguson, A.; Hynes, R.; Maoiléidigh, N.Ó.; Baker, N.; Cotter, D.; O’Hea, B.; Cooke, D.; Rogan, G.; et al. Fitness reduction and potential extinction of wild populations of Atlantic Salmon, Salmo salar, as a result of interactions with escaped farm salmon. Proc. R. Soc. Biol. Sci. 2003, 270, 2443-2450. [CrossRef]

19. Breau, C.; Cunjak, R.A.; Peake, S.J. Behaviour during elevated water temperatures: Can physiology explain movement of juvenile Atlantic salmon to cool water? J. Anim. Ecol. 2011, 80, 844-853. [CrossRef]

20. Daniels, J.M.; Chaput, G.J.; Carr, J. Estimating consumption rate of Atlantic Salmon smolts (Salmo salar) by Striped Bass (Morone saxatilis) in the Miramichi River estuary using acoustic telemetry. Can. J. Fish. Aquat. Sci. 2018, 75, 1811-1822. [CrossRef]

21. Chaput, G.; Douglas, S.G.; Hayward, J. Biological Characteristics and Population Dynamics of Atlantic Salmon (Salmo Salar) from the Miramichi River, New Brunswick, Canada; Fisheries and Oceans Canada: Ottawa, ON, Canada, 2016.

22. DFO. Spawner Abundance and Biological Characteristics of Striped Bass (Morone Saxatilis) in the Southern Gulf of St. Lawrence in 2015; Fisheries and Oceans Canada: Ottawa, ON, Canada, 2016.

23. Boreman, J.; Lewis, R.R. Atlantic coastal migration of striped bass. In Common Strategies of Anadromous and Catadromous Fishes; Dadswell, M.J., Klauda, J.R., Moffit, C.M., Rulifson, R.A., Saunders, R.L., Eds.; American Fisheries Society Symposium: Bethesda, MD, USA, 1987; pp. 331-339. 
24. Andrews, S.N.; Dadswell, M.J.; Buhariwalla, C.F.; Linnansaari, T.; Curry, R.A. Looking for Striped Bass in Atlantic Canada: The Reconciliation of Local, Scientific, and Historical Knowledge. Natl. Emerg. Number Assoc. 2019, 26, 1-30. [CrossRef]

25. Setzler, E.M.; Boynton, W.R.; Wood, K.V.; Zion, H.H.; Lubbers, L.; Mountford, N.K.; Frere, P.; Tucker, L.; Mihursky, J.A. Synopsis of Biological Data on Striped Bass, Morone Saxatilis (Walbaum); NOAA Technical Report, NMFS Circular 433: Seattle, WA, USA, 1980.

26. Field, J.D. Atlantic Striped Bass management: Where did we go right? Fisheries 1997, 22, 6-8.

27. Ficke, A.D.; Myrick, C.A.; Hansen, L.J. Potential impacts of global climate change on freshwater fisheries. Rev. Fish Biol. Fish. 2007, 17, 581-613. [CrossRef]

28. Coutant, C.C. Temperature-oxygen habitat for freshwater and coastal Striped Bass in a changing climate. Trans. Am. Fish. Soc. 1990, 119, 240-253. [CrossRef]

29. NunatuKavut Community Council (NCC). NunatuKavut Annual Report 2016-2017; NunatuKavut Community Council: Happy Valley-Goose Bay, NL, Canada, 2017.

30. DFO. Update of Indicators to 2017 of Adult Atlantic Salmon for the Miramichi River (NB), Salmon Fishing Area 16, DFO Gulf Region; Fisheries and Oceans Canada: Ottawa, ON, Canada, 2018.

31. Bradford, R.G.; Chaput, G.; Douglas, S.; Hayward, J. Status of Striped Bass (Morone saxatilis) in the Gulf of St. Lawrence in 1999; Canadian Stock Assessment Secretariat Research Document 2001/006; Department of Fisheries and Oceans: Ottawa, ON, Canada, 2001.

32. DFO. Spawner Abundance and Biological Characteristics of Striped Bass (Morone Saxatilis) in the Southern Gulf of St. Lawrence in 2017; DFO Canadian Science Advisory Secretariat Science Response 2018/016; Fisheries and Oceans Canada: Ottawa, ON, Canada, 2018.

33. Manooch, C.S. Food Habits and yearling and Adult Striped Bass, Morone saxatilis Walbaum, from Albemarle Sound, North Carolina. Cheasapeake Sci. 1973, 14, 73-86. [CrossRef]

34. Chaput, G.; Hardie, P.; Hayward, J.; Moore, D.; Shaesgreen, J.; Northumberland Salmon Protection Association. Migrations and Biological Characteristics of Atlantic Salmon (Salmo Salar) Smolts from the Northwest Miramichi River, 1998 to 2000; Canadian Technical Report of Fisheries and Aquatic Science 2415; Department of Fisheries and Oceans: Ottawa, ON, Canada, 2002.

35. Schulze, M.B. Using a Field Survey to Assess Potential Temporal and Spatial Overlap between Piscivores and Their Prey, and a Bioenergetics Model to Examine Potential Consumption of Prey, Especially Juvenile Anadromous Fish, in the Connecticut River Estuary. Master's Thesis, University of Massachusetts, Amherst, MA, USA, 1996.

36. Beland, F.B.; Kocik, J.F.; VandeSande, J.; Sheehan, T.F. Striped Bass predation upon Atlantic Salmon smolt in Maine. Natl. Emerg. Number Assoc. 2001, 8, 267-274.

37. Davis, J.P.; Schultz, E.T.; Vokoun, J.C. Striped Bass consumption of Blueback Herring during vernal riverine migrations: Does relaxing harvest restrictions on predators help conserve a prey species of concern? Mar. Coast. Fish. 2012, 4, 239-251. [CrossRef]

38. Dunning, D.J.; Waldman, J.R.; Ross, Q.E.; Mattson, M.T. Use of Atlantic Tomcod and other prey by Striped Bass in the lower Hudson River estuary during winter. Trans. Am. Fish. Soc. 1997, 126, 857-861. [CrossRef]

39. Buhariwalla, C.F.; MacMillan, J.L.; Gregoire, M.J.; Dadswell, M.J.; Stokesbury, M.J.W. Population characteristics of Striped Bass killed by cold shock during winter shutdown of a power plant in Nova Scotia. Natl. Emerg. Number Assoc. 2016, 23, 163-173. [CrossRef]

40. Gardinier, M.N.; Hoff, T.B. Diet of Striped Bass in the Hudson River Estuary. N. Y. Fish Game J. 1982, 29, 152-165.

41. Hyslop, E.J. Stomach analysis-A review of methods and their application. J. Fish Biol. 1980, 17, 411-429. [CrossRef]

42. Baker, R.; Buckland, A.; Sheaves, M. Fish gut content analysis: Robust measures of diet composition. Fish Fish. 2014, 15, 170-177. [CrossRef]

43. Davidson, V.M. Fish (Salmon) Management; Fisheries Research Board of Canada No. 427, Manuscript Reports of the Biological Stations; Fisheries Research Board of Canada: Toronto, ON, Canada, 1950.

44. Andrews, S.N.; Zelman, K.; Ellis, T.; Linnansaari, T.; Curry, R.A. Diet of Striped Bass and Muskellunge downstream of a large hydroelectric dam: A preliminary investigation into suspected Atlantic Salmon Smolt predation. N. Am. J. Fish. Manag. 2018, 38, 734-746. [CrossRef] 
45. Blackwell, F.B.; Juanes, F. Predation on Atlantic Salmon smolts by Striped Bass after dam passage. N. Am. J. Fish. Manag. 1998, 18, 936-939. [CrossRef]

46. Warner, J.; Kynard, B. Scavenger Feeding by Subadult Striped Bass, Morone saxatilis below a Low-Head hydroelectric Dam. Fish. Bull. 1986, 84, 220-222.

47. Kahnle, A.W.; Hattala, K.A. Striped Bass Predation on Adult American Shad: Occurrence and Observed Effects on American Shad Abundance in Atlantic Coastal Rivers and Estuaries; Supplement to American Shad Stock Assessment Report for Peer Review; Atlantic States Marine Fisheries Commission: Washington, DC, USA, 2007; Volume 1, pp. 182-220.

48. Dew, C.B. Stomach contents of commercially caught Hudson River Striped Bass, Morone saxatilis, 1973-1975. Fish. Biol. NOAA 1988, 86, 397-401.

49. Juanes, F. A length-based approach to predator-prey relationships in marine predators. Can. J. Fish. Aquat. Sci. 2016, 73, 677-684. [CrossRef]

50. Mihalitsis, M.; Bellwood, D.R. A morphological and functional basis for maximum prey size in piscivorous fishes. PLoS ONE 2017, 12, e0184679. [CrossRef] [PubMed]

51. Rudershausen, P.J.; Tuomikoski, J.E.; Buckel, J.A.; Hightower, J.E. Prey Selectivity and Diet of Striped Bass in western Albermarle Sound, North Carolina. Trans. Am. Fish. Soc. 2005, 134, 1059-1074. [CrossRef]

52. Chaput, G.; Douglas, S.G.; Hayward, J. Biological Characteristics and Population Dynamics of Atlantic Salmon (Salmo salar) from the Miramichi River, New Brunswick, Canada; Canadian Science Advisory Secretariat Research Document 2016/029; Department of Fisheries and Oceans: Gulf Region, Ottawa, ON, Canada, 2016.

53. Robichaud-Leblanc, K.A.; Courtenay, S.C.; Locke, A. Spawning and early life history of a northern population of Striped Bass (Morone saxatilis) in the Miramichi River estuary, Gulf of St. Lawrence. Can. J. Zoo 1996, 74, 1645-1655. [CrossRef]

54. McCoy, E.G. Quantitative Sampling of Striped Bass, Roccus Saxatilis (Walbaum), Eggs in the Roanoke River. Master's Thesis, North Carolina State University, Raleigh North, NC, USA, 1959.

55. Talbot, G.B. Estuarine Environmental Requirements and Limiting Factors for Striped Bass; Bureau of Sport Fisheries and Wildlife: United States Department of the Interior, Tiburon, CA, USA, 1966.

56. Rulifson, R.A.; Tull, K.A. Striped Bass spawning in a tidal bore river: The Shubenacadie Estuary, Atlantic Canada. Trans. Am. Fish. Soc. 1999, 128, 613-624. [CrossRef]

57. Douglas, S.G.; Chaput, G.; Hayward, J.; Sheasgreen, J. Pre-spawning, spawning, and post-spawning behavior of Striped Bass in the Miramichi River. Trans. Am. Fish. Soc. 2009, 138, 121-134. [CrossRef]

58. Walters, J.F., III; Austin, H.M. Diet composition of large Striped Bass (Morone saxatilis) in Chesapeake Bay. Fish. Bull. 2003, 101, 414-423.

59. DFO. Assessment of the Habitat Quality and Habitat Use by the Striped Bass Population of the St. Lawrence Estuary, Quebec; Canadian Science Advisory Secretariat Science Advisory Report 2010/069; Fisheries and Oceans Canada: Ottawa, ON, Canada, 2011.

60. Trent, L.; Hassler, W.W. Feeding behavior of adult Striped Bass, Roccus saxatilis, in relation to stages of sexual maturity. Chesapeake Sci. 1966, 7, 189-192. [CrossRef]

61. Scofield, E.C. The Striped Bass of California (Roccus Lineatus); Division of Fish and Game of California Fisheries, Bulletin No. 29: Sacramento, CA, USA, 1931.

62. Hollis, E.H. Variations in the feeding habits of the Striped Bass, Roccus saxatilis (Walbaum), in the Chesapeake Bay. Bull. Bingham Oceanogr. Collect. 1952, 14, 111-131.

63. Stevens, D.E. Food habits of Striped Bass, Roccus saxatilis, in the Sacramento-San Joaquin Delta. In Ecological Studies of the Sacramento-San Joaquin Delta, Part II: Fishes of the Delta; Turner, J.L., Kelly, D.W., Eds.; California Department of Fish and Game, Fisheries Bulletin: Sacramento, CA, USA, 1966; Volume 136, pp. 68-96.

64. Raney, E.C. The life history of the Striped Bass, Roccus saxatilis (Walbaum). Bull. Bingham Oceanogr. Collect. 1952, 14, 1-97.

65. Morgan, A.R.; Gerlach, A.R. Striped Bass Studies on Coos Bay, Oregon in 1949 and 1950: A Report to the Forty-Dixth Legislature; Oregon Fish Commission: Portland, OR, USA, 1950.

66. McLaren, J.B.; Cooper, J.C.; Hoff, T.B.; Lander, V. Movements of Hudson River Striped Bass. Trans. Am. Fish. Soc. 1981, 110, 158-167. [CrossRef]

67. Ferry, K.H.; Mather, M.E. Spatial and temporal diet patterns of subadult and small adult Striped Bass in Massachusetts estuaries: Data, a synthesis, and trends across scales. Mar. Coast. Fish. 2012, 4, 30-45. [CrossRef] 
68. Beukers-Stewart, B.D.; Jones, G.P. The influence of prey abundance on the feeding ecology of two piscivorous species of coral reef fish. J. Exp. Mar. Biol. Ecol. 2004, 299, 155-184. [CrossRef]

69. Stevens, R.E. Landlocked Striped Bass. Annu. Northeast Fish Wildl. Conf. 1969, 25, 2-11.

70. Mather, M.E.; Finn, J.T.; Ferry, K.H.; Deegan, L.A.; Nelson, G.A. Use of non-natal estuaries by migratory Striped Bass (Morone saxatilis) in summer. Fish. Bull. 2009, 107, 329-333.

71. Walter, J.F., III; Overton, A.S.; Ferry, K.H.; Mather, M.E. Atlantic coast feeding habits of Striped Bass: A synthesis supporting a coast-wide understanding of trophic biology. Fish. Manag. Ecol. 2003, 10, 349-360. [CrossRef]

72. Grossman, G.D.; Essington, T.; Johnson, B.; Miller, J.; Monsen, N.E.; Pearsons, T.N. Effects of Fish Predation on Salmonids in the Sacramento River-San Joaquin Delta and Associated Ecosystems; Delta Stewardship Council: Sacramento, CA, USA, 2013.

73. Sabal, M.; Hayes, S.; Merz, J.; Setka, J. Habitat alterations and a non-native predator, the Striped Bass, increase native Chinook salmon mortality in the Central Valley, California. N. Am. J. Fish. Manag. 2016, 36, 309-320. [CrossRef]

74. Schultz, A.A.; Kumagai, K.K.; Bridges, B.B. Methods to evaluate gut evacuation rates and predation using acoustic telemetry in the Tracy Fish Collection Facility primary channel. Anim. Biotelem. 2015, 3, 13. [CrossRef]

75. Schaefer, R.H. Feeding habits of Striped Bass from the surf waters of Long Island. N. Y. Fish Game J. 1970, 17, 1-17.

76. Jobling, M.; Breiby, A. The use and abuse of fish otoliths in studies of feeding habits of marine piscivores. Sarsia 1986, 71, 265-274. [CrossRef]

77. Campana, S.E. Photographic Atlas of Fish Otoliths of the Northwest Atlantic Ocean; NRC Research Press: Ottawa, ON, Canada, 2004.

78. Altin, A.; Ayyildiz, H. Relationships between total length and otolith measurements for 36 fish species from Gökçeada Island, Turkey. J. Appl. Ichthyol. 2017, 34, 136-141. [CrossRef]

79. González, A.F.; López, A.; Guerra, A.; Barreiro, A. Diets of marine mammals stranded on the northwestern Spanish Atlantic coast with special reference to Cephalopoda. Fish. Res. 1994, 21, 179-191. [CrossRef]

80. Gibson, J.F.; Halfyard, E.A.; Bradford, R.G.; Stokesbury, M.J.W.; Redden, A.M. Effects of predation on telemetry-based estimates: Insights from a study on endangered Atlantic Salmon smolts. Can. J. Fish. Aquat. Sci. 2015, 72, 728-741. [CrossRef]

81. Bradford, R.G.; Halfyard, E.A.; Hayman, T.; Leblanc, P. Overview of 2013 Bay of Fundy Striped Bass Biology and General Status; Fisheries and Oceans Canada: Ottawa, ON, Canada, 2015.

82. Lacroix, G.L.; Knox, D.; McCurdy, P. Effects of implanted dummy acoustic transmitters on juvenile Atlantic Salmon. Trans. Am. Fish. Soc. 2004, 133, 211-220. [CrossRef]

83. Wagner, G.N.; Cooke, S.J.; Brown, R.S.; Deters, K.A. Surgical implantation techniques for electronic tags in fish. Rev. Fish Biol. Fish. 2011, 21, 71-81. [CrossRef]

84. Collins, A.L.; Scott, S.G.; Welch, D.W.; Cooke, S.J.; Clarke, T.D. Intracoelomic acoustic tagging of juvenile sockeye salmon: Swimming performance, survival, and postsurgical wound healing in freshwater and during a transition to seawater. Trans. Am. Fish. Soc. 2013, 142, 515-523. [CrossRef]

85. Adams, N.S.; Rondorf, D.W.; Evans, S.D.; Kelly, J.E.; Perry, R.W. Effects of surgical and gastrically implanted radio transmitters on swimming performance and predator avoidance of juvenile Chinook salmon (Oncorhynchus tshawytscha). Can. J. Fish. Aquat. Sci. 1998, 55, 781-787. [CrossRef]

86. Voegeli, F.A.; Lacroix, G.L.; Anderson, J.M. Development of miniature pingers for tracking Atlantic Salmon smolts at sea. Hydrobiologica 1998, 371, 35-46. [CrossRef]

87. Melnychuk, M.C. Detection efficiency in telemetry studies: Definitions and evaluation methods. In Telemetry Techniques: A User Guide for Fisheries Research; Adams, N.S., Beeman, J.W., Eiler, J.H., Eds.; American Fisheries Society: Bethesda, MD, USA, 2012; pp. 339-357.

88. Wellborn, G.A.; Skelly, D.K.; Werner, E.E. Mechanisms creating community structure across a freshwater habitat gradient. Annu. Rev. Ecol. Evol. Syst. 1996, 27, 337-363. [CrossRef]

89. Jackson, D.A.; Peres-Neto, P.R.; Olden, J.D. What controls who is where in freshwater fish communities-the roles of biotic, abiotic, and spatial factors. Can. J. Fish. Aquat. Sci. 2001, 58, 157-170. 
90. Collie, J.S.; Botsford, L.W.; Hastings, A.; Kaplan, I.C.; Largier, J.L.; Livingston, P.A.; Plagányi, É.; Rose, K.A.; Wells, B.K.; Werner, F.E. Ecosystem models for fisheries management: Finding the sweet spot. Fish Fish. 2016, 17, 101-125. [CrossRef]

91. Walters, C.; Christensen, V.; Fulton, B.; Smith, A.D.; Hilborn, R. Predictions from simple predator-prey theory about impacts of harvesting forage fishes. Ecol. Model. 2016, 337, 272-280. [CrossRef]

92. Gjelland, K.Ø.; Hedger, R.D. Environmental influence on transmitter detection probability in biotelemetry: Developing a general model of acoustic transmission. Multistate Essay Exam. 2013, 4, 665-674. [CrossRef]

93. Kessel, S.T.; Cooke, S.J.; Heupel, M.R.; Hussey, N.E.; Simpfendorfer, C.A.; Vagle, S.; Fisk, A.T. A review of detection range testing in aquatic passive acoustic telemetry studies. Rev. Fish Biol. Fish. 2014, 24, 199-218. [CrossRef]

94. Robichaud-LeBlanc, K.A.; Courtenay, S.C.; Hanson, J.M. Ontogenetic diet shifts in age-0 Striped Bass, Morone saxatilis, from the Miramichi River estuary, Gulf of St. Lawrence. Can. J. Zoo 1997, 75, 1300-1309. [CrossRef]

95. Smircich, M.G. Long-Term Feeding Ecology of Early-Stage Striped Bass (Morone Saxatilis) and American Shad (Alosa Sapidissima) in the Hudson River Estuary. Master's Thesis, University of Connecticut, Mannsfield, CT, USA, 2016.

96. Jordan, R.C.; Juanes, F. Ontogenetic shifts in feeding habits of juvenile Striped Bass (Morone saxatilis) in the mid-Hudson River estuary. In Final Reports of the Tibor T. Polgar Fellowship Program 1998; Nieder, W.C., Waldman, J.R., Eds.; Hudson River Foundation: New York, NY, USA, 1999.

97. Howe, D.V.; Juanes, F. Habitat variation and the diet, growth, and conditions of juvenile Striped Bass (Morone saxatilis) in the mid-Hudson River Estuary. In Final Reports of the Tibor T. Polgar Fellowship Program 1999; Nieder, W.C., Waldman, J.R., Eds.; Hudson River Foundation: New York, NY, USA, 2000.

98. Jordan, R.C.; Howe, D.V.; Hurst, T.P.; Juanes, F. Feeding Habits of Age-0 Striped Bass, Morone saxatilis, in the Mid-Hudson River Estuary: Temporal, Spatial, and ontogenetic Variation. Estuaries 2003, 26, 1486-1493. [CrossRef]

99. Curran, H.W.; Ries, D.T. Fisheries investigations in the lower Hudson River. In A Biological Survey of the Lower Hudson Watershed, Supplement to the Twenty-Sixth Annual Report, 1936; Moore, E., Ed.; New York State Department of Conservation, Albany: New York, NY, USA, 1937; pp. 124-145.

100. Buckel, J.A.; McKown, K.A. Competition between juvenile Striped Bass and Bluefish: Resource partitioning and growth rate. Mar. Ecol. Progress. Ser. 2002, 234, 191-204. [CrossRef]

101. Melvin, G. A Survey of Striped Bass (Morone Saxatilis) in Kouchibouguac National Park, New Brunswick; Parks Canada, St.: Andrews, NB, Canada, 1979.

102. Rulifson, R.A.; McKenna, S.A. Food of Striped Bass in the Upper Bay of Fundy, Canada. Trans. Am. Fish. Soc. 1987, 116, 119-122. [CrossRef]

103. Leim, A.H. The fauna of Minas Channel, Minas Basin and the Shubenacadie River. Atl. Biol. Sta Orig. MS 1931, 278, 1-46.

104. Wilkinson, E.B. Consumptive and Non-Consumptive Effects of Predatory Fishes on Lobster in Southern Maine. Master's Thesis, University of New England, Biddeford, ME, USA, January 2013.

105. Nelson, G.A.; Chase, B.C.; Stockwell, J. Food habits of Striped Bass (Morone saxatilis) in coastal waters of Massachusetts. J. Northwest Fish. Sci. 2003, 32, 1-25. [CrossRef]

106. Sagarese, S.R.; Cerrato, R.M.; Frisk, M.G. Diet composition and feeding habits of common fishes in Long Island bays, New York. Natl. Emerg. Number Assoc. 2011, 18, 291-314. [CrossRef]

107. Merriman, D. Studies on the Striped Bass (Roccus saxatilis) of the Atlantic coast. U.S. Fishery Bulletin. U. S. Fish Wildl. Serv. 1941, 50,1-77.

(C) 2019 by the authors. Licensee MDPI, Basel, Switzerland. This article is an open access article distributed under the terms and conditions of the Creative Commons Attribution (CC BY) license (http://creativecommons.org/licenses/by/4.0/). 